\title{
Framework for Handling Modern Machinaries in Large Scal Industries
}

\author{
A. Ravi Kumar, S. Praveen Kumar
}

\begin{abstract}
The search for a theory of Industrial Relations has led to the emergence of a plethora of frameworks, of analysis of Industrial Relations. Making sense of the diverse perspectives involved has become as problematic as the original search itself. This paper re-visits the search for a theory of Industrial Relations by imposing an order on some dominant schools of thought in the literature, starting with the subject-matter and approach debate. The paper concludes that the subject-matter of Industrial Relations has evolved from being unions, to institutions of job regulation (rules), and then to conflict; and these correspond with the Union, Rules, and Conflict frameworks of Industrial Relations analysis suggested here. Consequently, it is the view of this paper that these should be seen as the components of the subject-matter of Industrial Relations; and given its multi-disciplinary nature, a web-of-discipline approach is more appropriate in Industrial Relations theorizing.
\end{abstract}

KEYWORDS: Unions, Rules, Conflict, Multi-Disciplinary, Web-of-Discipline

\section{INTRODUCTION}

Industrial Relations is a field of study and practice dealing with a set of interactions at the workplace predicated upon employment contract involving work parties and their definition are: study field/practice, set of interactions, employment contract, work parties' representatives, and job regulation. It started with the factory employment system consequent upon the industrial revolution of the 18th century. It has since developed into an independent discipline with its own jargon and increased significance in society. However, there is still a debate over what really is its focus and approach with scholars having different perspectives. Girigiri (2002), gave a sample of these perspectives to include: System, Oxford, Industrial Sociology, Unitary, Industrial Conflict, Class Conflict, Integrated, and Political Economic perspectives or approaches. According to Green (1994), even attempts at defining its content by focusing on certain institutions, characteristics, procedures and topics have not solved its problem of definition and analysis. Industrial Relations, indeed, has been in search of conceptual and analytical frameworks. Such frameworks are expected to provide it with distinctive and integrative concepts,

Revised Manuscript Received on December 16, 2019

Dr. A. Ravi Kumar, Associate Professor, Department of Science and Humanities, BIHER, Chennai, Tamilnadu.

S Praveen Kumar, Department of Science and Humanities, Bharath Institute of Higher Education and Research, Tambaram, Indi representatives in job regulation. The meaning givers in this

methodologies and theories. They constitute the approaches to the study and practice of Industrial Relations. Many scholars have acknowledged this search. For instance, Flanders (1965) appealed for "a distinctive industrial relations" and that "the study of Industrial Relations has had little theoretical content". Dunlop (1958) observed that: Mountains of facts have been piled up on the plains of human ignorance. The result is a glut of raw materials... Facts have outrun ideas. Integrating theory has lagged far behind expanding experience.

Gill (1969) concluded that the main difficulty in the study of industrial relations is "the absence of a suitable conceptual framework to act as a heuristic device in structuring the data"; hence the search for such a framework; a search not made easy by the controversy over what the subject matter of Industrial Relations is and what approach should be used in studying it. This paper, through a survey of literature, seeks to examine the subject-matter and approach debate using three frameworks of analysis: Union, Rules and Conflict Frameworks of Industrial Relations analysis.

\section{THE SUBJECT-MATTER AND APPROACH DEBATE}

The search for a theory of Industrial Relations (IR) started with the debate as to what should be the core or focus of IR. Up to the end of the Second World War, trade unionism was the center of IR theory. IR analysis was dominated with trade union issues; first with economic bias, followed by a political bias, and then a combination of economic and political approaches. While Dunlop (1958) described a trade union as an economic institution attempting to maximize some wage or employment dimensions of its members, Ross (1948) described it as a political institution working in an economic context with "orbits of coercive comparison" determining common wage policy. Again, while Commons (1925) described labour union, as a liberating force, which helped establish constitutional government in industry and delineate the power of one of the parties over the other, Perlman (1949) described a union as a design, to protect workers' job interests and job sharing opportunities.

The approach to build IR theory around trade unionism gave way to others that progressed from unionism to collective bargaining, social sub-systems and interrelationships amongst parties at the workplace. In Chamberlain and Kuhn's (1965) view, the center of IR is collective bargaining for the sale of labour; form of industrial government, and a method of management. For Flanders and Clegg (1954), IR is part of the
Blue Eyes Intelligence Engineering \& Sciences Publication 
social system. It encompasses the influence of the process of industrialization on the behaviour of men and societies and deals with the inter-relationships of management, labour and government (Kerr et al, 1973). In Behrend's (1963) view, IR deals with motivation, power struggle between management and union and the importance of institutional and economic background. This view somehow suggests the element of conflict that has come within the focus of IR theory.

The second aspect of the search for a theory of IR involves the debate whether or not IR should adopt a multi-disciplinal approach. It has been observed that IR is at a crossroad where a number of disciplines have met. These disciplines include history, economics, government, sociology, psychology and law. As a result of this, some authors have argued that IR should be multi-disciplinary in approach. Such writers (Johnnie, 1988) have criticized Dunlop's (1958) and Wood et al's (1975) works as building a disciplinary fortress around sociology and economics, rather than hemming in other disciplines as an attempt in unifying Industrial Relations as a genuine discipline.

On the other hand, most functional specialists fear that a multi-disciplinary approach would tear the subject apart by concentrating attention on some of its aspects to the exclusion or comparative neglect of others. Pushing this view further is Gill's (1969) assertion that:

All these disciplines and others have their contributions to make but the lack of an integrating conceptual scheme has resulted in poor communications across boundaries and indeed has, perhaps, obscured full explanation by over simplification of the many sided complexity of the problems under consideration (in IR).

To alley the fear of the proponents of this view, it has been suggested that IR employs a "web of disciplines" approach; as more shall be gain if young disciplines such as IR "pinch chunks" from other established disciplines.

We have so far examined the debate on the subject matter and disciplinary approach of IR. Our purpose for this examination is to create the necessary background for the articulation of the theories of IR and the approaches they suggest for the study of IR. Since it is possible today to define Economics as the "theory of ends-means relationships" and Political Science as the "theory of power relationships", one wishes to ask: "IR is a theory of what?" We have built up sufficient evidence to provide an answer to this question; and this evidence lies in the shifting of focus from trade unionism to job regulation and conflict. Consequently it is possible to conceive three analytical frameworks, theories or approaches of Industrial Relations. These are the Union, Rules and Conflict Frameworks.

\section{UNION FRAMEWORK OF INDUSTRIAL RELATIONS}

The Trade Union approach to Industrial Relations conceives Industrial Relations as the relationships amongst unions, and the institutions and processes that have developed to structure them. Unions as used here refer to industrial unions, which include trade unions and employers' association. Within the trade unions could be found associations of senior employees (staff associations) on one hand and junior employees (labour unions) on the other. The interactions amongst the members of these unions either as individuals with collectivities or collectivities with collectivities are examined in this approach as constituting Industrial Relations.

In a second dimension, this approach provides for the analysis of the role of government as an intervention into the basic relationships between employer or employers' association and employees or their unions. Where even government is treated as an employer, its interventionist roles constitute a different unit of analysis. Thus, government legislations and policies, made to influence relations between employers and employees in a country, are expected to be complied with by government as an employer.

With unions as the fundamental unit of analysis, this approach proceeds to examine the processes, context and institutions involved in their (unions) interactions. It is from this standpoint that all the issues conceivable in today's Industrial Relations are often analyzed. For instance, the unions are shown as they participate in collective bargaining, organizational governance, dispute, grievance and disciplinary procedures etc. The unions are shown in terms of how they are influenced by factors within industry and the larger society. Unions, therefore, constitute the pivot of analysis in this framework of Industrial Relations. In fact, it will not be out of place to describe IR within this framework or approach as a theory of industrial unions in enterprise management.

An example of this framework of, or approach to, Industrial Relations could be found in the works Akpala (1982), Fashoyin (1980) and Ananaba (1969). For these scholars, Industrial Relations is the study of trade unions, collective bargaining and the roles of government. Every other aspect of Industrial Relations is accidental to these. For instance, Fashoyin described the aim of his work thus: to study the changing roles of government, character of trade unions and the effects of these changes, on labour-management relations at the workplace. This perhaps explains why the emphasis in his work was on a tripartite model of collective bargaining - one having employees' union, management or employers' association and government.

The problem with this approach to Industrial Relations is that it is historical and descriptive. In other words, it is less analytical and explanatory. Often the history, development, and roles of industrial unions are given. The role of government is described. In narratives, the environmental, legal and institutional frameworks of IR are stated. Discussion of all of these and other relevant Industrial Relations issues is rarely along the part of a network of variables analytically isolated for the provision of explanation, prediction and control of such variable. While some understanding is offered, it is doubtful if the ultimate purpose of theory is served sufficiently via this approach. In fact, the approach could be described as being a-theoretical. Consequently,

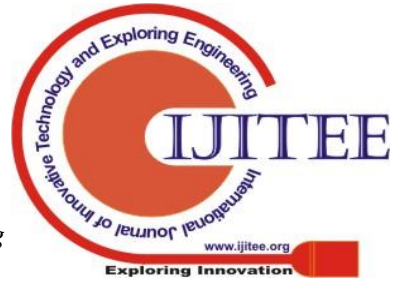


the search for a better framework of Industrial Relations analysis continued; and the Rules Framework emerged.

\section{CONFLICT FRAMEWORK OF INDUSTRIAL RELATIONS}

What we wish to describe as the Conflict framework in Industrial Relations theory is what is commonly referred to as the Sociological approach to Industrial Relations analysis. Our preference for the concept of "Conflict", instead of "Sociological", is informed by the observations that even the earlier discussed approaches have some sociological underpinnings and the core of what has been described as the sociological approach is conflict. So to tag one approach as sociological does not only suggest that the others are "non-sociological" but it also misses the distinguishing core of the approach or is rather vague in implying it. What perhaps explains the "sociological" nomenclature for the approach could have been the title of the work or model by

Margerison (1969), that has dominated the approach. Margerison (1969), a leading proponent of this approach, criticized the Rules approach. According to him, rule making is by no means the core of IR and that Flanders' (1965) concept of IR as a system of rules narrows the scope of IR inquiry to the regulation of conflict. The consequence of this is a concentration on the effects and resolution of conflicts rather than on its nature and development (causes). He argued that:

It would appear, therefore, that industrial relations as it is at presently construed is more concerned with studying the resolution of industrial conflict than its generation. The emphasis tends, therefore, to be put more on the consequences of industrial dispute than on its causes. It would seem from Flanders' views that industrial relations problems do not arise until they are within the formal orbit of the rules of the industrial relations systems. To counter this, I would suggest that conflict is the basic concept that should form the basis of the study of industrial relations.

To him, the rules school adopts a curative approach to conflict; and since this is faulty, he suggested a preventive approach to conflict. Against this background of a preventive, instead of a curative, philosophy to industrial conflict, Margerison opined that, all interpersonal behaviour must be part of industrial relations which he defined as the "study of people in a situation interacting in the doing of work in relation to some form of contract wither written or unwritten".

He conceived Industrial Relations as a social system consisting of two levels: the plant social system and national social system. These give rise to two major conceptual levels of Industrial Relations, two major sociological models of conflict, and the use of a multi-disciplinary approach. He further asserted that, Industrial Relations have functional areas and corresponding academic areas. While the former are Contractual, Organizational and Interpersonal relations, the latter include Economics and Law, Politics and Sociology, and Social psychology respectively - the basis of the multi- disciplinary approach.
A third model of the conflicts approach to IR could be found in the Marxian literature. In fact, it will be out of place to say that both the Margerison's (1969) sociologist model and Fox's (1966) pluralist model have their roots in the Marxist approach (Green, 1994; Barret et al, 1975). Although Marx (1971) did not put forward a specific theory of IR, his general theory of dialectic materialism has relevant provisions that have helped the study, explanation and understanding of IR. For our purposes here, we shall list the relevant tenets of the theory. They include the following:

- Society is made up of two conflicting classes (the capitalist, bourgeois or employers and workers, proletariat, or employees). While the capitalists own the means of production, the workers own labour which creates wealth.

- These two classes are always at war because of an irreconcilable conflict of interests. The capitalist appropriates the wealth created by labour and leaves labour with nothing more than what is required for subsistence.

- The class war will lead to a socialist revolution that will bring about a classless communist society. In this revolution, the proletariat (employees) will over throw the bourgeoisie (employers).

- Conflict in the industry is a reflection of the conflict in the society. As such the industry will equally experience a revolution that will place labour in the governance of industry.

\section{V.CONCLUSIONS}

This paper examined the theoretical frameworks or foundations of Industrial Relations. Three key frameworks were examined namely the Union, Rules and Conflict Frameworks of Industrial Relations analysis in addition to the subject-matter and approach debate. Findings from the literature are that: Though Union, Institutions of job regulation, and Conflict had been dominant themes of Industrial Relations at different times in its evolution, the three are needed to have a comprehensive view of the subject-matter of Industrial Relations. Given its multi-disciplinary nature and the tendency of scholars from different discipline to want to route for the dominance of their respective disciplines hemming in the contributions of the different disciplines for a distinctive and integrated field of study and practice, the web-of-discipline approach seems to be more satisfactory. Within the Union's framework, Industrial Relations could be seen as a theory of union in enterprise management It is a theory of the rules governing work parties and their relationships when viewed from the Rules' framework. The Conflict framework asserts Industrial Relations as a theory of conflict inherit in the relationships amongst work parties within and outside industry. Each of these provides us with different views of IR through their various models. All of them have their strong points as well as weak points. Despite their strengths and weaknesses, they have been presented here as separate approaches to the analysis of IR. It is, however, possible to find or apply elements that cut across the

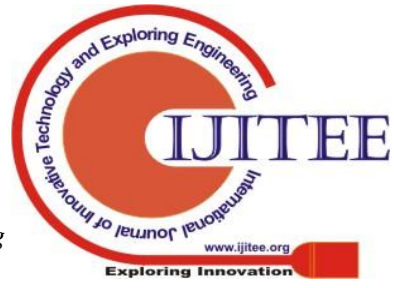


three in the study. So the choice of what perspective or approach to take depends on a number of factors which include: analytical convenience, parsimony and contingency of thought.

\section{REFERENCES}

1. Madni, A. M. (2007). Designing for resilience. ISTI Lecture notes on advanced topics in systems engineering.

2. Obiekwe, O., Felix, O. \& Izim, B. (2018). Industrial relations environment in Nigeria: Implications for managers in Nigeria workplace. International Journal of Economics and Business Management, 4 (1): 1 10

3. Oyebanji, J. (1994). Indian business environment and organization effectiveness. Abiola Bookshop Limited.

4. Oyeyinka, O. (1989) Nigeria's steel needs in 1990s. Management in Nigeria, 25 (2):8. Setyendra (2014). Industrial relations. Retrieved from: http://is patgure.com/industrial- relations/

5. Seville, E. (2008) Brunsdon, D., Dantas, A., Le Masurler, Wilkinson, S. \& Vargo, J. (2008). Organizational resilience: researching the reality of New Zealand Organization. Journal of Business and Continuity and Emergency Management, 2 (2): 258 - 266.

6. R.J., Shanwal, V.K. and Mandal, M.K. (eds), Emotional Intelligence Theoretical and Cultural Perspectives, New York: Nova Science Publishers Inc.

7. Dr. Chandra Mohan, A and Prasad, B. V. S, "Emotional Intelligence and Self Motivational Factors for Managerial Effectiveness in the Corporate World", National Monthly Refereed Journal Of Research In Commerce \& Management, Volume No.1, Issue No.11.

8. Hassan Jorfi, "The impact of emotional intelligence on communication effectiveness: Focus on strategic alignment", African Journal of Marketing Management, Vol. 6(5), pp. 82-87, October, 2014.

9. M.Suvarchala Rani, "Emotional Intelligence - A Model for Effective Leadership, Competency and Career Growth", Indian Journal of Science and Technology, Vol 8 (S4), 240-246, February 2015.

10. Vladimir, "Project Managers Emotional Intelligence - A Ticket to Success", Journal in Procedia - Social and Behavioral Sciences, 74,274 $284,2013$.

\section{AUTHORS PROFILE}

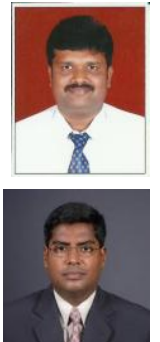

Dr. A.Ravi Kumar, Associate Professor, Department of Science and Humanities, BIHER, Chennai, Tamilnadu

S. Praveen Kumar Department of Science and Humanities Bharath Institute of Higher Education and Research, India 